\title{
Artificial Diels-Alderase based on the transmembrane protein FhuA
}

\author{
Hassan Osseili ${ }^{\ddagger 1}$, Daniel F. Sauer ${ }^{\ddagger 1}$, Klaus Beckerle ${ }^{1}$, Marcus Arlt ${ }^{2}$, Tomoki Himiyama ${ }^{3}$, \\ Tino Polen ${ }^{4}$, Akira Onoda ${ }^{3}$, Ulrich Schwaneberg ${ }^{2}$, Takashi Hayashi ${ }^{3}$ and Jun Okuda*1
}

\section{Full Research Paper}

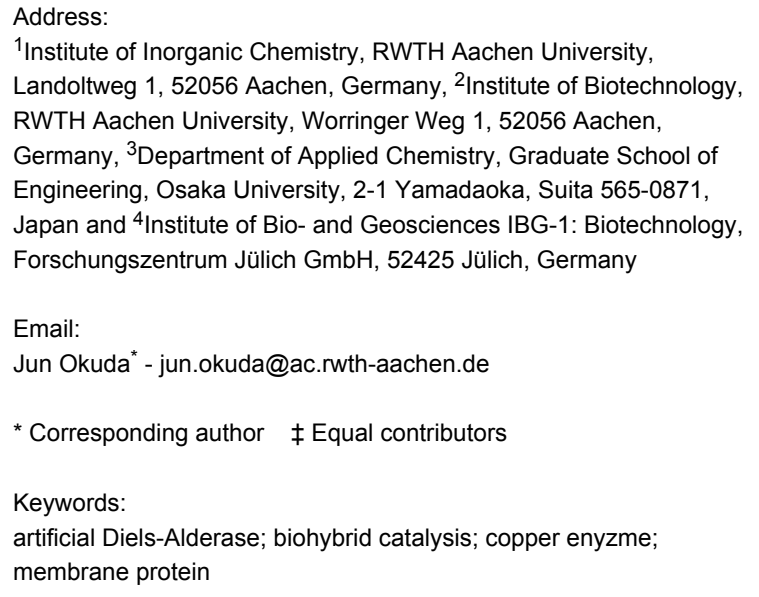

Beilstein J. Org. Chem. 2016, 12, 1314-1321. doi:10.3762/bjoc. 12.124

Received: 02 April 2016

Accepted: 10 June 2016

Published: 24 June 2016

This article is part of the Thematic Series "Organometallic chemistry".

Guest Editor: L. Gade

(C) 2016 Osseili et al.; licensee Beilstein-Institut. License and terms: see end of document.

\begin{abstract}
Copper(I) and copper(II) complexes were covalently linked to an engineered variant of the transmembrane protein Ferric hydroxamate uptake protein component $A$ (FhuA $\Delta \mathrm{CVF}^{\text {tev }}$ ). Copper(I) was incorporated using an $N$-heterocyclic carbene (NHC) ligand equipped with a maleimide group on the side arm at the imidazole nitrogen. Copper(II) was attached by coordination to a terpyridyl ligand. The spacer length was varied in the back of the ligand framework. These biohybrid catalysts were shown to be active in the Diels-Alder reaction of a chalcone derivative with cyclopentadiene to preferentially give the endo product.
\end{abstract}

\section{Introduction}

So-called artificial metalloenzymes have attracted attention over the last decade [1-9]. Incorporation of an organometallic cofactor into proteins offers new possibilities to expand the reaction repertoire catalyzed by natural enzymes to non-natural reactions. With this approach man-made metalloproteins as asymmetric transfer hydrogenases [10,11], Suzukiases [12], metatheases [13-20], epoxidases [21], Diels-Alderases [22-27] and others have been reported. The Diels-Alder reaction is a powerful $\mathrm{C}-\mathrm{C}$ bond formation reaction, widely used in organic chemistry, e.g., for the synthesis of natural products [28]. This reaction is known to be catalyzed by Lewis acids such as a $\mathrm{Cu}$ (II) complex [29]. Additionally, structurally defined catalysts are found to influence the endo/exo ratio as well as the enantioselectivity [30]. Artificial Diels-Alderases have also been reported to show good endo/exo selectivities as well as high enantioselectivities in a benchmark reaction of azachalcone with cyclopentadiene [22-27].

The artificial Diels-Alderases reported so far used soluble proteins, where the binding site of $\mathrm{Cu}(\mathrm{II})$ was formed either by site- 
directed mutagenesis [22,23], by incorporation of a suitable ligand, or copper complex in an apo-protein [24-27]. Here we report on the use of the robust transmembrane protein Ferric hydroxamate uptake protein component $A(\mathrm{FhuA})$ as host for defined $\mathrm{Cu}(\mathrm{I}) \mathrm{NHC}$ or $\mathrm{Cu}(\mathrm{II})$ terpyridyl complexes with a maleimide moiety. By covalently bonding these copper complexes to the protein artificial Diels-Alderases based on a membrane protein have been obtained.

\section{Results and Discussion}

\section{Synthesis of the metal complexes}

As the protein host, the FhuA $\Delta \mathrm{CVF}^{\text {tev }}$ variant of the Ferric hydroxamate uptake protein component $A$ (FhuA) was chosen [31]. This protein was shown to be suitable to harbor Grubbs-Hoveyda type catalysts for olefin metathesis $[17,18]$.
To anchor $\mathrm{Cu}(\mathrm{I})$ in the protein FhuA $\Delta \mathrm{CVF}^{\text {tev }}$ that contains a cysteine residue at position 545 for conjugation [31], an NHC ligand containing a maleimide function was prepared (Scheme 1).

The imidazolium salt $\mathbf{3}$ was synthesized by nucleophilic substitution of mesityl imidazol 1 with maleimide derivative $\mathbf{2}$. These salts were used to generate the $\mathrm{Cu}(\mathrm{I}) \mathrm{NHC}$ complexes $\mathbf{4}$ upon deprotonation with $\mathrm{K}_{2} \mathrm{CO}_{3}$. Complex 4 contains only one $\mathrm{NHC}$ ligand at the copper, as shown by elemental analysis and ESIMS. Attempts to coordinate $\mathrm{Cu}(\mathrm{II})$ to the NHC ligand failed. However, the terpyridyl (terpy) ligand is a promising candidate to support $\mathrm{Cu}$ (II) ions. Therefore, the terpy framework containing an alcohol function on the 4 position of the central pyridine was chosen (Scheme 2).

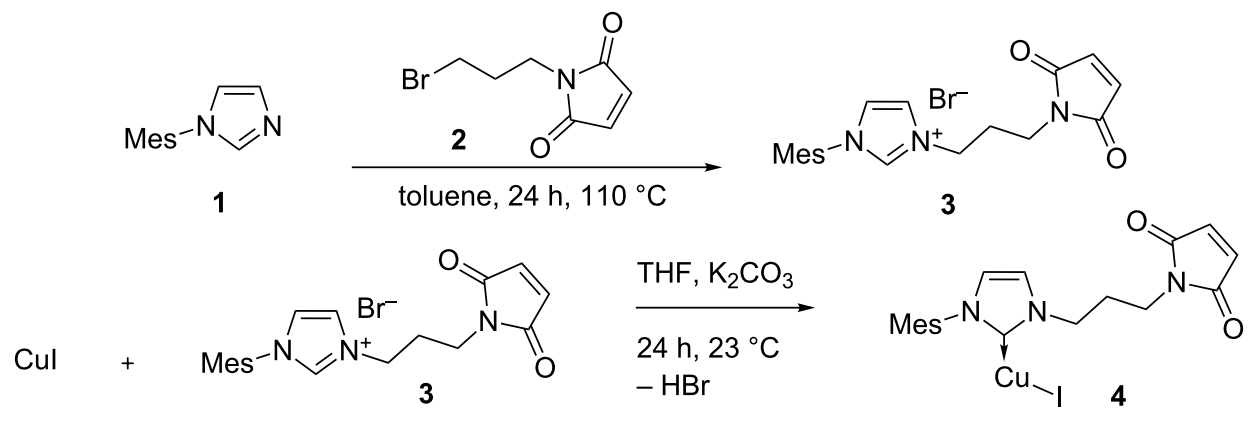

Scheme 1: Syntheses to $\mathrm{Cu}(\mathrm{I})$ complex bearing a NHC ligand.

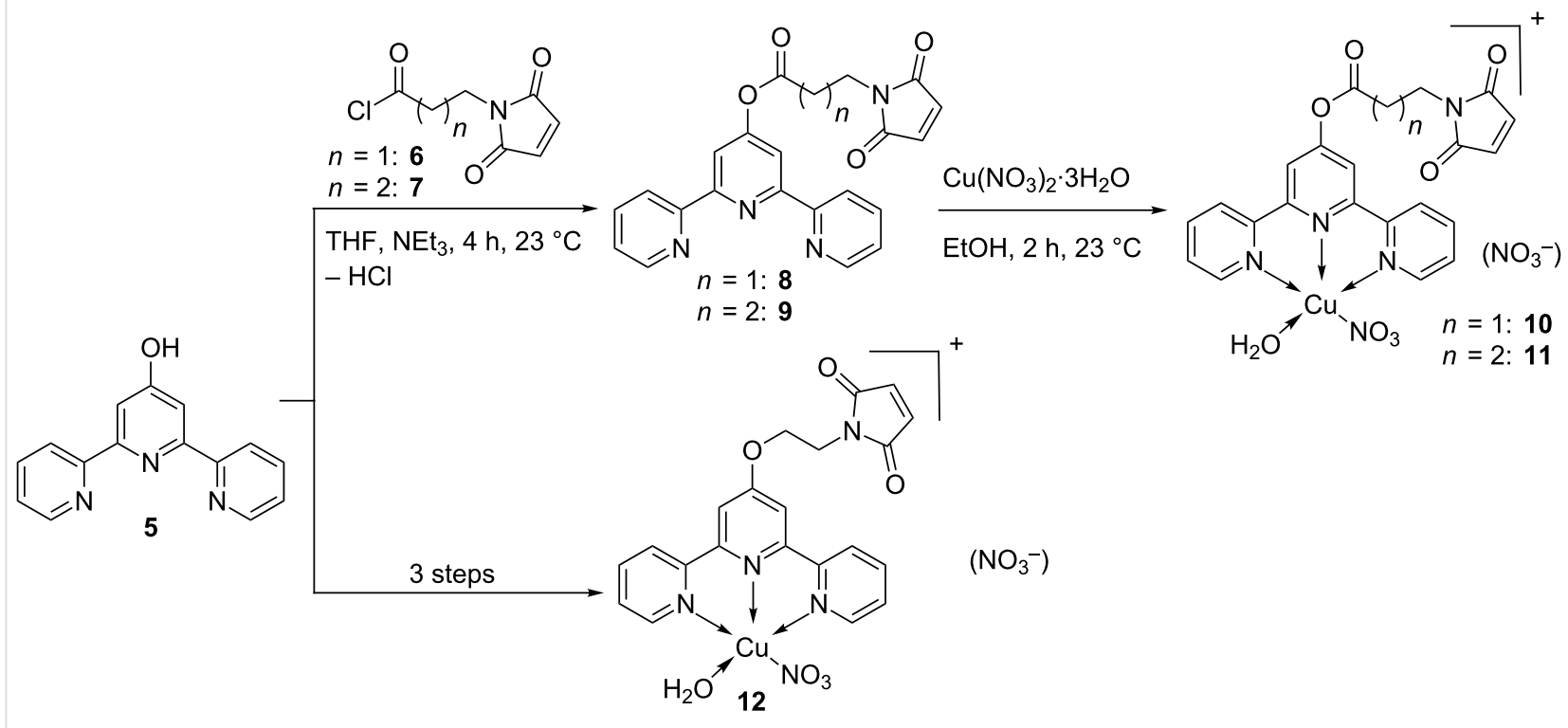


By either esterification or nucleophilic attack, the spacer with the maleimide group was attached. The ligand was treated with one equivalent of $\mathrm{Cu}\left(\mathrm{NO}_{3}\right)_{2} \cdot 3 \mathrm{H}_{2} \mathrm{O}$ leading to the $\mathrm{Cu}$ (II) complexes 10-12.

By using the established anchoring strategy, the $\mathrm{Cu}(\mathrm{I})$ and $\mathrm{Cu}(\mathrm{II})$ complexes (4 and 10-12) were anchored covalently inside the $\beta$-barrel structure. After anchoring, the protein was refolded by dialysis (Scheme 3).

Anchoring of all complexes was successful. Titration of the free cysteine with the fluorescence dye ThioGlo ${ }^{\circledR}$ indicated that more than $95 \%$ of the cysteine residues were conjugated for each catalyst.

Renaturing of the protein was successful in the case of the terpy ligand framework (for clarity of the location of the catalyst, see Figure S1 in Supporting Information File 1). After 3 days of dialysis against SDS-solution, excess catalyst 10-12 was removed. Additional 3 days of dialysis against PE-PEG solution renatured the protein structure to give the expected $\beta$-barrel structure, as indicated by CD spectra (Figure 1).

The CD spectra show a minimum at around $215 \mathrm{~nm}$ and a maximum at $195 \mathrm{~nm}$, as expected for $\beta$-barrel proteins such as FhuA [17,18,31]. This finding suggests correct refolding of the protein. Additionally, the temperature stability of the new conjugate 17 was evaluated.

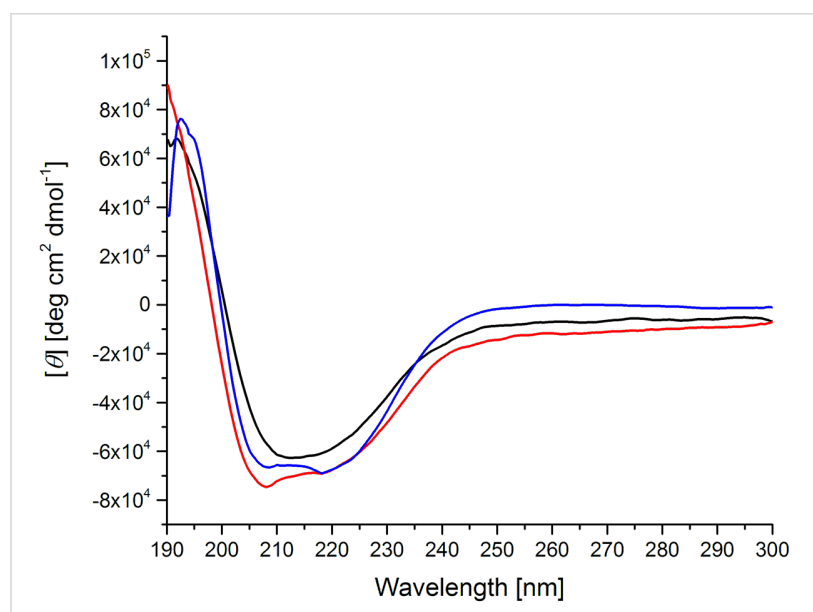

Figure 1: CD spectra of refolded catalysts 17-19 (red: 17, black: 18, blue: 19$)$.

The temperature-dependent $\mathrm{CD}$ spectra indicate correct folding of the catalyst in the temperature range from $4{ }^{\circ} \mathrm{C}$ to $64{ }^{\circ} \mathrm{C}$ (Figure 2). This is in agreement with previously reported stability analysis of the wild-type FhuA and the FhuA mutant with its "cork" domain removed (FhuA $\Delta 1-159$ ) [31].

The $\mathrm{Cu}(\mathrm{I})$ NHC-containing protein could not be renatured. We speculate that during the refolding procedure $\mathrm{Cu}(\mathrm{I})$ was oxidized to $\mathrm{Cu}$ (II) by contamination with air. $\mathrm{Cu}$ (II) led to protein aggregation and precipitation. This was shown in an independent experiment. When one equiv of $\mathrm{Cu}\left(\mathrm{NO}_{3}\right)_{2} \cdot 3 \mathrm{H}_{2} \mathrm{O}$ was

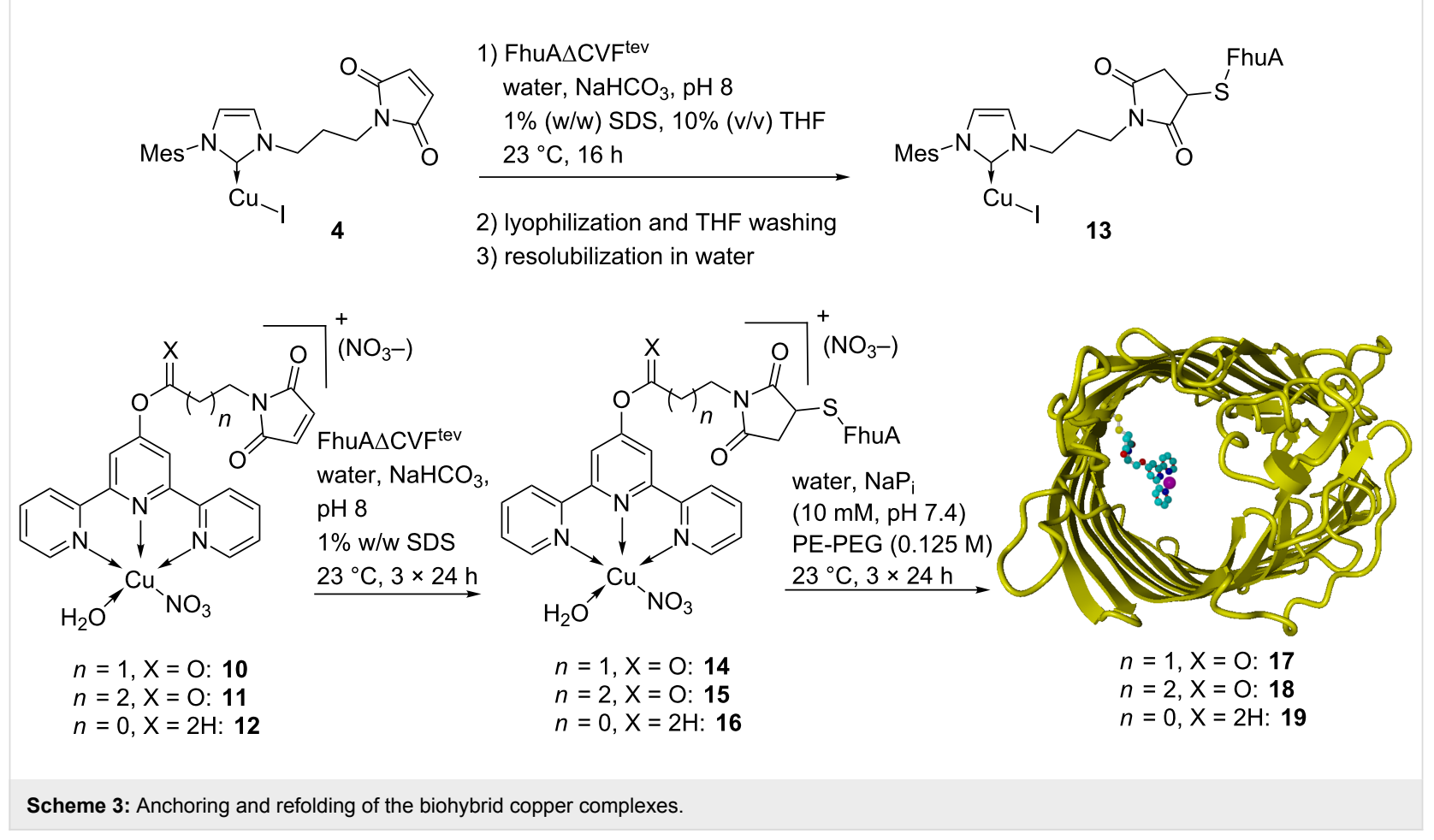




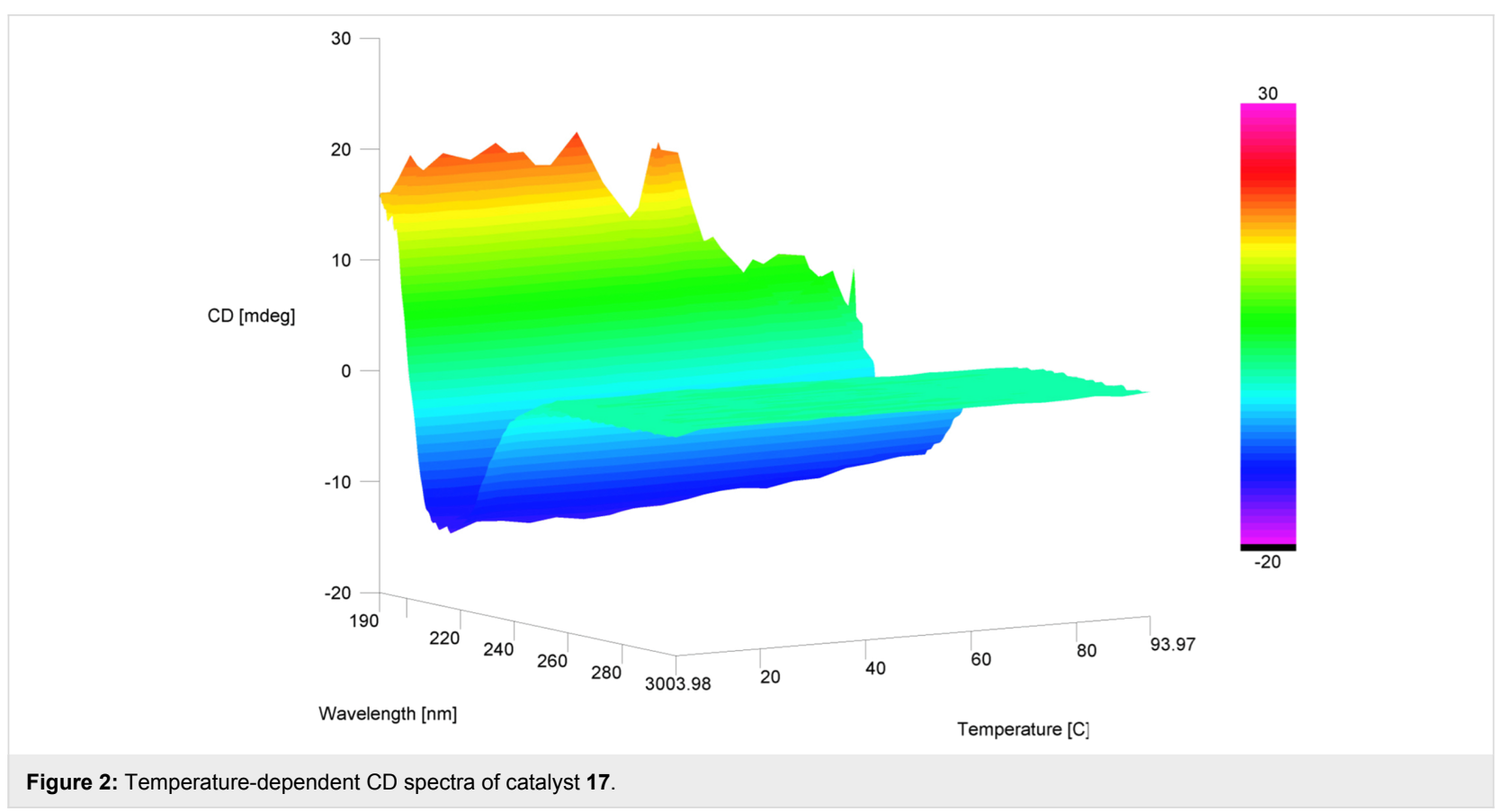

added to a solution of FhuA $\triangle \mathrm{CVF}^{\text {tev }}$, the protein precipitated rapidly and quantitatively.

MALDI-TOF-MS analysis for the whole biohybrid catalyst was difficult due to the high mass of approximately $64 \mathrm{kDa}$. However, digestion into smaller fragments is possible with the deliberately introduced TEV cleavage site $[17,18]$. The fragment containing the $\mathrm{Cu}$ complex was cut out and analyzed separately (Figure 3 ).

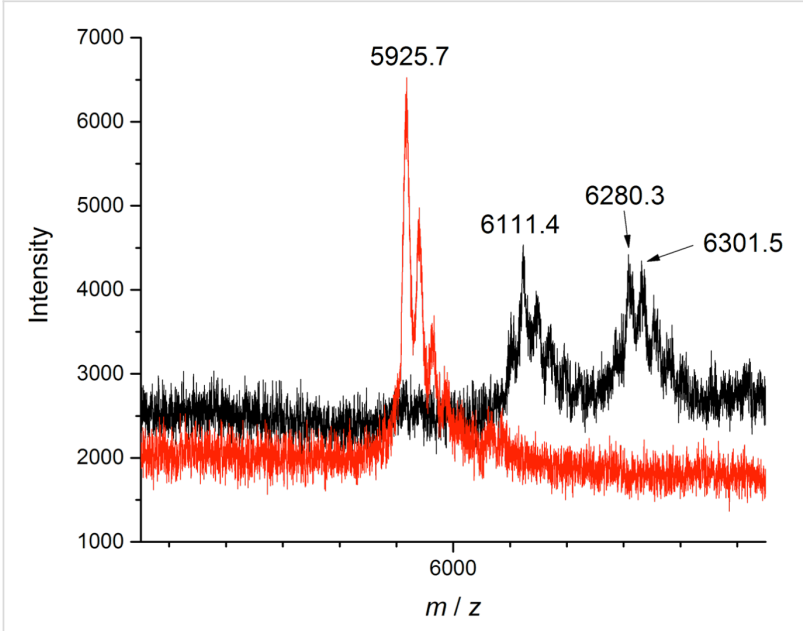

Figure 3: MALDI-TOF mass spectra (black: 17, red: FhuA $\triangle C \mathrm{CF}^{\mathrm{tev}}$ ).

Digestion of biohybrid catalyst $\mathbf{1 7}$ was successful. Comparison of the MALDI-TOF- MS spectrum with FhuA $\triangle \mathrm{CVF}^{\text {tev }}$ (calcd $\left(\mathrm{M}+\mathrm{Na}^{+}\right): m / z=5925 \mathrm{Da}$; found: $\left.m / z=5925 \mathrm{Da}\right)$ indicates successful coupling. The signal of $m / z=6301 \mathrm{Da}$ indicates the FhuA fragment with the attached ligand framework (calcd $(\mathrm{M})$ : $m / z=6302 \mathrm{Da}$; found: $m / z=6301 \mathrm{Da})$. The signal of $m / z=6111$ Da results from saponification of the ester and the maleimide moiety (calcd $\left(\mathrm{M}+\mathrm{H}_{2} \mathrm{O}+\mathrm{Na}^{+}\right): m / z=6111 \mathrm{Da}$, found: $m / z=6111 \mathrm{Da}$ ). We were unable to detect the copper ion in the MALDI-TOF-MS.

The isolated biohybrid catalysts were tested in the Diels-Alder reaction of azachalcone $\mathbf{2 0}$ and cyclopentadiene (21, Table 1). We evaluated first the background reaction of this Diels-Alder reaction in the detergents and buffer solutions we used for the biohybrid catalysts. Since SDS precipitates at $4{ }^{\circ} \mathrm{C}$ and the solution becomes heterogeneous, we decided to perform the reactions in SDS at $23{ }^{\circ} \mathrm{C}$. After 3 days, the reaction showed $62 \%$ conversion with an endo to exo ratio of 70:30 (Table 1, entry 2). Since detergents such as SDS influences the reaction significantly, this value is in good agreement with previously reported results [32]. In PE-PEG at $4{ }^{\circ} \mathrm{C}$ the conversion was lower; the endo/exo ratio was ca. 55:45 (Table 1, entry 1). Using $\mathrm{CuI}$ in SDS, the conversion increased slightly, showing the same selectivity (Table 1 , entry 5 ). When using $\mathrm{Cu}$ (II) as a catalyst, the conversion was complete in both detergent solutions, but no change in selectivity was observed (Table 1, entries 3 and 4). CuI NHC complex 4 showed the same activity and selectivity as $\mathrm{CuI}$ (Table 1, entry 6). By using the bioconjugate 13 , the conversion with $62 \%$ is comparable with the protein-free catalysts or $\mathrm{CuI}$ itself, but the selectivity significantly changed the endo product preferred (Table 1, entry 7). By using the $\mathrm{Cu}$ (II) complexes 10-12 in the refolding buffer: the conver- 
Table 1: Diels-Alder reaction catalyzed by the biohybrid catalysts.<smiles>O=C(/C=C/c1ccccc1)c1ccccn1</smiles>

20

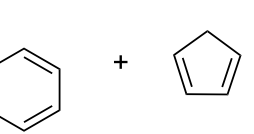

21
$1 \mathrm{~mol} \%$ catalyst

water, buffer, $20 \%(\mathrm{v} / \mathrm{v}) \mathrm{THF}$

4 or $23^{\circ} \mathrm{C}, 72 \mathrm{~h}$

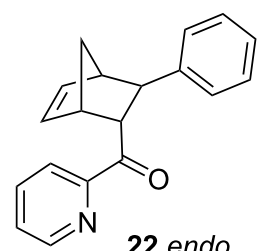

22 endo

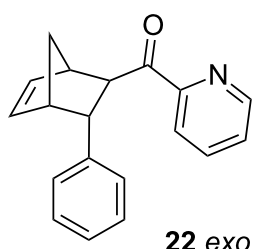

22 exo

\begin{tabular}{|c|c|c|c|c|c|}
\hline Entry & Catalyst & Buffer & Temp. $\left[{ }^{\circ} \mathrm{C}\right]$ & Conv. ${ }^{a}[\%]$ & endolexo ${ }^{b}$ \\
\hline 1 & - & PE-PEG ${ }^{C}$ & 4 & 20 & $55 / 45$ \\
\hline 2 & - & $\operatorname{SDS}^{d}$ & 23 & 62 & $70 / 30$ \\
\hline 3 & $\mathrm{Cu}\left(\mathrm{NO}_{3}\right)_{2} \cdot 3 \mathrm{H}_{2} \mathrm{O}$ & PE-PEG ${ }^{C}$ & 4 & 95 & $54 / 46$ \\
\hline 4 & $\mathrm{Cu}\left(\mathrm{NO}_{3}\right)_{2} \cdot 3 \mathrm{H}_{2} \mathrm{O}$ & $\operatorname{SDS}^{d}$ & 23 & 94 & $65 / 35$ \\
\hline 5 & Cul & $\operatorname{SDS}^{d}$ & 23 & 78 & $70 / 30$ \\
\hline 6 & 4 & $\operatorname{SDS}^{d}$ & 23 & 75 & $67 / 33$ \\
\hline 7 & 13 & $\operatorname{SDS}^{d}$ & 23 & 62 & $90 / 10$ \\
\hline 8 & 10 & PE-PEG ${ }^{C}$ & 4 & 21 & $65 / 35$ \\
\hline 9 & 11 & PE-PEG ${ }^{C}$ & 4 & 33 & $56 / 44$ \\
\hline 10 & 12 & PE-PEG ${ }^{C}$ & 4 & 12 & $66 / 34$ \\
\hline 11 & 14 & $\operatorname{SDS}^{d}$ & 23 & 92 & $90 / 10$ \\
\hline 12 & 15 & $\operatorname{SDS}^{d}$ & 23 & 87 & $89 / 11$ \\
\hline 13 & 16 & $\operatorname{SDS}^{d}$ & 23 & 91 & $89 / 11$ \\
\hline 14 & 17 & PE-PEG ${ }^{\mathrm{C}}$ & 4 & 69 & $96 / 4$ \\
\hline 15 & 18 & PE-PEG ${ }^{C}$ & 4 & 15 & $66 / 34$ \\
\hline 16 & 19 & PE-PEG ${ }^{c}$ & 4 & 64 & $98 / 2$ \\
\hline
\end{tabular}

aDetermined by ${ }^{1} \mathrm{H}$ NMR in $\mathrm{CDCl}_{3}$ and HPLC. b ${ }^{\mathrm{b}}$ Determined by HPLC. ${ }^{\mathrm{c} P E}-\mathrm{PEG}(0.125 \mathrm{M})$, sodium phosphate buffer (100 mM, $\left.\mathrm{pH} 7.4\right)$. dSDS (1\% w/w), pH 7.5 (adjusted with $\mathrm{NaHCO}_{3}$ ).

sion decreased with an endo/exo ratio of approximately $60 / 40$ (Table 1, entry 8-10). Upon attaching the catalyst to the protein in the partially folded state, the selectivity increased to $90 \%$ endo with high conversions independent of the spacer length (Table 1, entry 11-13). The refolded biohybrid catalysts 17 and 19 showed good conversion with almost quantitative endo product formation (Table 1, entries 14 and 16). Catalyst 18 with the longest spacer unit, however, showed moderate activity and loss of endo selectivity. This is explained by the high flexibility of this catalyst within the $\beta$-barrel structure of the refolded protein (Table 1, entry 15). Based on these catalysis results, we hypothesize that the protein environment is sterically rather demanding, which is even more pronounced in the refolded state. The absence of any enantioselectivity suggests that no preferential orientation of the substrate at the active site within the barrel structure is possible. Notably, no protein precipitated during catalysis, showing the advantageous feature of membrane proteins in terms of robustness as compared to soluble proteins [15].

\section{Conclusion}

Herein, we report the synthesis of $\mathrm{Cu}(\mathrm{I}) \mathrm{NHC}$ and $\mathrm{Cu}(\mathrm{II})$ terpyridyl complexes equipped with a maleimide moiety which underwent covalent conjugation at the cysteine residue 545 of the transmembrane protein FhuA $\triangle C_{V F}{ }^{\text {tev }}$. These biohybrid conjugates were analyzed by CD spectroscopy, MALDI-TOF-MS, ThioGlo fluorescence titration, and BCA assay. All employed methods indicate the folded structure of FhuA $\triangle \mathrm{CVF}^{\text {tev }}$ and a high occupancy of the only accessible cysteine residue within this $\beta$-barrel protein.

The biohybrid catalysts showed high activity and high endo selectivity in the Diels-Alder reaction of substrate $\mathbf{2 0}$ with cyclopentadiene (21). A comparison with other reported artificial Diels-Alderases is not meaningful because of the utilization of detergents in the present case, which increases the stability towards the Diels-Alder reaction conditions. However, similar trends with respect to both activity and endo selectivity were observed. The cavity of FhuA appears to enhance the reaction as reported by Hayashi et al. for nitrobindin [26], Reetz et al. for serum albumin [22,23], and Roelfes et al. for Lactococcal multidrug resistance Regulator (LmrR) [25]. Furthermore, the increased endo selectivity is in agreement with other protein-modified catalysts reported so far [22-27]. 


\section{Experimental}

\section{General considerations}

All manipulations were performed under argon atmosphere using standard Schlenk or glove box techniques. Prior to use, glassware was dried overnight at $130{ }^{\circ} \mathrm{C}$ and solvents were dried, distilled and degassed using standard methods. Catalysis with $\mathrm{Cu}$ (II) complexes were performed under ambient conditions. NMR measurements were performed on a Bruker Avance II 400 or a Bruker Avance III HD 400 spectrometer at ambient temperature unless otherwise mentioned. The chemical shifts $(\delta \mathrm{ppm})$ in the ${ }^{1} \mathrm{H}$ and ${ }^{13} \mathrm{C}$ NMR spectra were referenced to the residual proton signals of the deuterated solvents and reported relative to tetramethylsilane [33]. Abbreviations for NMR spectra: s (singlet), d (doublet), t (triplet), quint (quintet), m (multiplet). Elemental analyses were performed on an elementar vario EL machine. CD spectra were recorded on a JASCO J-1100 equipped with a single position Peltier cell holder. MALDI-TOF spectra were recorded on an Ultraflex III TOF/ TOF mass spectrometer (Bruker Daltonics). High resolution ESI-TOF-MS were performed on a Thermo Finnigan LCQ Deca XP Plus spectrometer. $\mathrm{CuI}$ and $\mathrm{Cu}\left(\mathrm{NO}_{3}\right)_{2} \cdot 3 \mathrm{H}_{2} \mathrm{O}$ were purchased from Sigma-Aldrich and used as recieved. Cyclopentadiene was freshly distilled before used. Compounds 1 [34], 2 [35], 5 [36], 6 [37], 7 [37], 12 [26], 20 [32] and FhuA $\Delta \mathrm{CVF}^{\text {tev }}$ [17] were synthesized according to literature procedures.

\section{Syntheses}

\section{Synthesis and characterization of $\mathrm{IMesBr} 3$}

A solution of 1-(3-bromopropyl)-1H-pyrrol-2,5-dione (1.69 g, $7.75 \mathrm{mmol}, 1.00$ equiv) and 1 -(mesityl)- $1 H$-imidazole (1.66 g, $8.91 \mathrm{mmol}, 1.10$ equiv) in toluene $(35 \mathrm{~mL})$ was stirred in a closed Schlenk tube for $24 \mathrm{~h}$ at $110^{\circ} \mathrm{C}$. The colorless precipitate was filtered, washed with toluene $(3 \times 15 \mathrm{~mL})$ and dried under vacuum to afford analytically pure imidazolium salt 1 (2.58 g, $6.40 \mathrm{mmol}, 83 \%)$ as colorless powder. ${ }^{1} \mathrm{H} \mathrm{NMR}$ $\left(400 \mathrm{MHz}, \mathrm{CD}_{2} \mathrm{Cl}_{2}\right) \delta 10.32(\mathrm{~s}, 1 \mathrm{H}, \mathrm{NCHN}), 8.07(\mathrm{~s}, 1 \mathrm{H}$, $\mathrm{CH}=\mathrm{CH}), 7.28(\mathrm{~s}, 1 \mathrm{H}, \mathrm{CH}=\mathrm{CH}), 7.05(\mathrm{~s}, 2 \mathrm{H}$, aryl $\mathrm{CH}), 6.73$ (s, $2 \mathrm{H}, \mathrm{CH}=\mathrm{CH}), 4.68\left(\mathrm{t},{ }^{3} J_{\mathrm{HH}}=6.85 \mathrm{~Hz}, 2 \mathrm{H}, \mathrm{CH}_{2}\right), 3.58\left(\mathrm{t},{ }^{3} J_{\mathrm{HH}}\right.$ $\left.=6.42 \mathrm{~Hz}, 2 \mathrm{H}, \mathrm{CH}_{2}\right), 2.35\left(\mathrm{~s}, 3 \mathrm{H}, p-\mathrm{CH}_{3}\right), 2.34$ (quint, $\left.{ }^{3} J_{\mathrm{HH}}=6.72 \mathrm{~Hz}, 2 \mathrm{H}, \mathrm{CH}_{2}\right), 2.10(\mathrm{~s}, 6 \mathrm{H}, o-\mathrm{Me}) ;{ }^{13} \mathrm{C} \mathrm{NMR}(100$ $\left.\mathrm{MHz}, \mathrm{CD}_{2} \mathrm{Cl}_{2}\right) \delta 171.5(C=\mathrm{O}), 141.9,139.0(\mathrm{NCHN}), 135.0$ $(\mathrm{CH}=\mathrm{CH}), 134.9,131.3,130.2,123.8(\mathrm{CH}=\mathrm{CH}), 123.7,48.0$ $\left(\mathrm{CH}_{2}\right), 34.5\left(\mathrm{CH}_{2}\right), 30.2\left(\mathrm{CH}_{2}\right), 21.4$ (p-Me), 18.0 (o-Me); ESIMS (+) $m / z(\%)$ : calcd for $\left(\mathrm{C}_{19} \mathrm{H}_{22} \mathrm{~N}_{3} \mathrm{O}_{2}\right)^{+}, 324.171$; found, 324.170 (100).

\section{Synthesis and characterization of $\mathrm{NHC}-\mathrm{Cu}(\mathrm{I}) \mathrm{I}$ complex 4}

The Imidazolium salt 3 (200 $\mathrm{mg}, 0.495 \mathrm{mmol}, 1.00$ equiv), $\mathrm{K}_{2} \mathrm{CO}_{3}$ (280 mg, $2.02 \mathrm{mmol}, 4.00$ equiv) and $\mathrm{CuI}$ (95 mg, $0.495 \mathrm{mmol}, 1.00$ equiv) was stirred in THF $(5 \mathrm{~mL})$ for $24 \mathrm{~h}$ at
$23{ }^{\circ} \mathrm{C}$. The solvent was evaporated under vacuum and the residue was dissolved in dichloromethane $(4 \mathrm{~mL})$. After filtering over Celite ${ }^{\circledR}$ the solvent was evaporated under vacuum and the residue dried under vacuum to afford $\mathrm{CuI}$ NHC complex 6 (150 mg, $0.292 \mathrm{mmol}, 59 \%$ ) as orange powder. ${ }^{1} \mathrm{H} \mathrm{NMR}$ $\left(400 \mathrm{MHz}, \mathrm{CDCl}_{3}\right) \delta 7.19(\mathrm{~s}, 1 \mathrm{H}, \mathrm{CH}=\mathrm{CH}), 7.28(\mathrm{~s}, 1 \mathrm{H}$, $\mathrm{CH}=\mathrm{CH}), 6.93(\mathrm{~s}, 2 \mathrm{H}$, aryl $\mathrm{CH}), 6.83(\mathrm{~s}, 2 \mathrm{H}, \mathrm{CH}=\mathrm{CH}), 4.21(\mathrm{t}$, $\left.{ }^{3} J_{\mathrm{HH}}=6.72 \mathrm{~Hz}, 2 \mathrm{H}, \mathrm{CH}_{2}\right), 3.58\left(\mathrm{t},{ }^{3} J_{\mathrm{HH}}=6.72 \mathrm{~Hz}, 2 \mathrm{H}, \mathrm{CH}_{2}\right)$, $2.31(\mathrm{~s}, 3 \mathrm{H}, p-\mathrm{Me}), 2.16$ (quint, $\left.{ }^{3} J_{\mathrm{HH}}=6.72 \mathrm{~Hz}, 2 \mathrm{H}, \mathrm{CH}_{2}\right), 2.00$ (s, 6H, o-Me); ${ }^{13} \mathrm{C}$ NMR (100 MHz, $\left.\mathrm{CDCl}_{3},\right) \delta 181.7(\mathrm{NCN})$, $170.6(C=\mathrm{O}), 139.0,135.4,134.9,134.2,129.1121 .7,120.6$, $48.3\left(\mathrm{CH}_{2}\right), 34.7\left(\mathrm{CH}_{2}\right), 30.5\left(\mathrm{CH}_{2}\right), 21.0(p-M e), 17.9(o-M e)$; Anal. calcd for $\mathrm{C}_{19} \mathrm{H}_{21} \mathrm{CuIN}_{3} \mathrm{O}_{2}, \mathrm{C}, 44.41 ; \mathrm{H}, 4.36 ; \mathrm{N}, 8.18$; found: C, 44.02; H, 4.01; N, 7.75; ESIMS (+) $m / z(\%)$ : calcd for $\left(\mathrm{C}_{19} \mathrm{H}_{21} \mathrm{CuN}_{3} \mathrm{O}_{2}\right)^{+}$388.092; found, 388.106 (100).

\section{Synthesis of terpyridyl ligands 8 and $\mathbf{9}$}

A solution of terpyridine $\mathbf{5}$ (200 $\mathrm{mg}, 0.803 \mathrm{mmol}, 1.00$ equiv) in THF $(10 \mathrm{~mL})$ was treated with acid chloride $6(165 \mathrm{mg}$, $0.884 \mathrm{mmol}, 1.10$ equiv) or 7 (177 mg, $0.884 \mathrm{mmol}, 1.10$ equiv) in THF $(5 \mathrm{~mL})$. Triethylamine $\left(\mathrm{NEt}_{3}\right)(222 \mu \mathrm{L}, 1.61 \mathrm{mmol}$, 2.00 equiv) was added to the solution and the mixture was stirred for $16 \mathrm{~h}$ at $23{ }^{\circ} \mathrm{C}$. The solution was filtered and all volatiles evaporated. The residue was dissolved in dichloromethane $(50 \mathrm{~mL})$, washed twice with water $(50 \mathrm{~mL})$, and once with brine $(50 \mathrm{~mL})$. The organic layer was dried over $\mathrm{Na}_{2} \mathrm{SO}_{4}$ and the solvent removed under vacuum affording the terpyridine ligand $\mathbf{8}$ (285 mg, $0.715 \mathrm{mmol}, 89 \%$ ) or 9 (280 mg, $0.699 \mathrm{mmol}, 87 \%$ ). ${ }^{1} \mathrm{H}$ NMR (8, $\left.400 \mathrm{MHz}, \mathrm{CD}_{2} \mathrm{Cl}_{2}\right) \delta 8.69(\mathrm{~m}, 2 \mathrm{H}$, aryl $\mathrm{CH}), 8.60$ $\left(\mathrm{dt},{ }^{3} J_{\mathrm{HH}}=8.0 \mathrm{~Hz},{ }^{3} J_{\mathrm{HH}}=1.0 \mathrm{~Hz}, 2 \mathrm{H}\right.$, aryl $\left.\mathrm{CH}\right), 8.26(\mathrm{~s}, 2 \mathrm{H}$, aryl $\mathrm{CH}), 7.86(\mathrm{~m}, 2 \mathrm{H}$, aryl $\mathrm{CH}), 7.34\left(\mathrm{ddd},{ }^{3} J_{\mathrm{HH}}=7.4 \mathrm{~Hz}\right.$, ${ }^{3} J_{\mathrm{HH}}=4.8 \mathrm{~Hz},{ }^{3} J_{\mathrm{HH}}=1.1 \mathrm{~Hz}, 2 \mathrm{H}$, aryl $\left.\mathrm{CH}\right), 6.75(\mathrm{~s}, 2 \mathrm{H}$, $H \mathrm{C}=\mathrm{CH}), 4.00\left(\mathrm{t},{ }^{3} J_{\mathrm{HH}}=7.0 \mathrm{~Hz}, 2 \mathrm{H}, \mathrm{CH}_{2}\right), 2.99(\mathrm{t}$, $\left.{ }^{3} J_{\mathrm{HH}}=7.0 \mathrm{~Hz}, 2 \mathrm{H}, \mathrm{CH}_{2}\right) \mathrm{ppm} ;{ }^{1} \mathrm{H} \mathrm{NMR}\left(\mathbf{9}, 400 \mathrm{MHz}, \mathrm{CD}_{2} \mathrm{Cl}_{2}\right)$ $\delta 8.69(\mathrm{~m}, 2 \mathrm{H}$, aryl $\mathrm{CH}), 8.61\left(\mathrm{dt},{ }^{3} J_{\mathrm{HH}}=7.8 \mathrm{~Hz}\right.$, ${ }^{3} J_{\mathrm{HH}}=1.1 \mathrm{~Hz}, 2 \mathrm{H}$, aryl $\left.\mathrm{CH}\right), 8.25(\mathrm{~s}, 2 \mathrm{H}$, aryl $\mathrm{CH}), 7.85(\mathrm{~m}$, $2 \mathrm{H}$, aryl CH), $7.34\left(\mathrm{ddd},{ }^{3} J_{\mathrm{HH}}=7.4 \mathrm{~Hz},{ }^{3} J_{\mathrm{HH}}=4.9 \mathrm{~Hz},{ }^{3} J_{\mathrm{HH}}=\right.$ $1.0 \mathrm{~Hz}, 2 \mathrm{H}$, aryl $\mathrm{CH}), 6.75(\mathrm{~s}, 2 \mathrm{H}, H \mathrm{C}=\mathrm{C} H), 3.71\left(\mathrm{t},{ }^{3} J_{\mathrm{HH}}=6.8\right.$ $\mathrm{Hz}, 2 \mathrm{H}, \mathrm{CH}_{2}$ ), $2.67\left(\mathrm{t},{ }^{3} J_{\mathrm{HH}}=7.4 \mathrm{~Hz}, 2 \mathrm{H}, \mathrm{CH}_{2}\right.$ ), 2.09 (pent, ${ }^{3} J_{\mathrm{HH}}=7.2 \mathrm{~Hz}, 2 \mathrm{H}, \mathrm{CH}_{2}$ ) ppm.

\section{Synthesis of $\mathrm{Cu}(\mathrm{II})$-terpyridine complexes 10 and 11}

To a solution of terpyridine ligand $8(200 \mathrm{mg}, 0.500 \mathrm{mmol}$, 1.00 equiv) or 9 (207 mg, $0.500 \mathrm{mmol}, 1.00$ equiv) in ethanol ( $10 \mathrm{~mL}), \mathrm{Cu}\left(\mathrm{NO}_{3}\right)_{2} \cdot 3 \mathrm{H}_{2} \mathrm{O}(120 \mathrm{mg}, 0.500 \mathrm{mmol}, 1.00$ equiv) in ethanol was added. The solution was stirred for $2 \mathrm{~h}$ at $23{ }^{\circ} \mathrm{C}$. The blue precipitate was collected and washed generously with cold THF $(20 \mathrm{~mL})$, cold ethanol $(50 \mathrm{~mL})$ and cold dichloromethane $(10 \mathrm{~mL})$. The residue was dried under vacuum, to give the copper complex 10 (214 mg, $0.365 \mathrm{mmol}, 73 \%)$ or 11 (207 mg, $0.345 \mathrm{mmol}, 69 \%)$. ESIMS (10) (+) $\mathrm{m} / z(\%)$ : calcd for 
$\left(\mathrm{C}_{22} \mathrm{H}_{16} \mathrm{CuN}_{4} \mathrm{O}_{4}\right)^{+}, 463.0468$; found, 463.0459 (35); calcd for: $\left(\mathrm{C}_{15} \mathrm{H}_{10} \mathrm{CuN}_{3} \mathrm{O}\right)^{+}, 311.0125$; found, 311.0118 (43); ESIMS (11) $(+) \mathrm{m} / z(\%)$ : calcd for $\left(\mathrm{C}_{23} \mathrm{H}_{18} \mathrm{CuN}_{4} \mathrm{O}_{4}\right)^{+}, 477.0624$; found, 477.0624 (7); calcd for $\left(\mathrm{C}_{15} \mathrm{H}_{10} \mathrm{CuN}_{3} \mathrm{O}\right)^{+}$; 311.0125; found: 311.0114 (36).

\section{General procedure: Conjugation of the catalysts to FhuA $\triangle \mathrm{CVF}{ }^{\text {tev }}$ and refolding}

To a degassed solution of FhuA $\Delta \mathrm{CVF}^{\text {tev }}$ in water $(5 \mathrm{mg} / \mathrm{mL}$, $\left.\mathrm{pH} \approx 8\left(\mathrm{NaHCO}_{3}\right)\right)$ containing $1 \%(\mathrm{w} / \mathrm{w})$ SDS, 10 equiv of catalyst 4 in degassed THF $(10 \%(\mathrm{v} / \mathrm{v}))$ or 10 equiv of catalyst $\mathbf{1 0}$, 11, 12 in water $(10 \%(\mathrm{v} / \mathrm{v}))$ was added. The solution was allowed to stir $16 \mathrm{~h}$.

In the case of catalyst 4 , water was removed in vacuum, and the residue was washed with degassed THF $(4 \times 15 \mathrm{~mL})$ to remove excess of catalyst 4 . The residue was dried in vacuum and dissolved in water.

In the case of catalyst 10-12, the solution was transferred into a dialysis tube and the solution was dialyzed for 3 days against 200 fold volume containing SDS $(1 \%(\mathrm{w} / \mathrm{w}))$ and water $(\mathrm{pH} \approx 8$ $\left(\mathrm{NaHCO}_{3}\right)$ ). The dialysis solution was changed every 12 hours. Afterwards, the sample was dialyzed for 2 days against 200 fold volume containing the refolding detergent PE-PEG $(0.125 \mathrm{mM}$, average $\left.M_{\mathrm{n}}=2250 \mathrm{~g} / \mathrm{mol}\right)$, sodium phosphate buffer $(10 \mathrm{mM}$, $\mathrm{pH}$ 7.4), and water. The dialysis solution was changed every $12 \mathrm{~h}$.

The protein concentration was analyzed by BCA assay, the coupling efficiency was determined by ThioGlo fluorescence titration, and correct refolding was determined by CD spectroscopy, as previously reported $[17,18]$. Digestion of the proteins was performed as previously reported [17].

\section{General procedure: Diels-Alder reaction}

To the corresponding catalyst ( $1 \mathrm{~mol} \%$ ) in $2 \mathrm{~mL}$ of buffer solution (0.125 mM PE-PEG, sodium phosphate buffer (100 mM, $\mathrm{pH}$ 7.4), $1 \mathrm{mM}$ EDTA) at $4{ }^{\circ} \mathrm{C}$ or $23{ }^{\circ} \mathrm{C}$ azachalcone 20 (4 mg, $0.02 \mathrm{mmol})$ in THF $(10 \%(\mathrm{v} / \mathrm{v}))$ and freshly distilled cyclopentadiene ( $40 \mu \mathrm{L}, 50 \mu \mathrm{M}, 33$ equiv) was added subsequently. The reaction mixture was stirred for $72 \mathrm{~h}$. Afterwards, the mixture was extracted with $\mathrm{Et}_{2} \mathrm{O}(3 \times 10 \mathrm{~mL})$, the combined organic phases were dried over $\mathrm{Na}_{2} \mathrm{SO}_{4}$ and the solvent removed under reduced pressure. The residue was analyzed by ${ }^{1} \mathrm{H}$ NMR spectroscopy and chiral phase HPLC using heptane/isopropanol $(98: 2)$ as eluents. All reactions were carried out in triplicates.

\section{Abbreviations}

PE-PEG (polyethylene-polyethylene glycol), SDS (sodium dodecyl sulfate), TEV (Tobacco Etch Virus),
MALDI-TOF-MS (matrix-assisted laser desorption/ionisation and time-of-flight mass spectrometry), FhuA $\Delta \mathrm{CVF}^{\text {tev }}$ (FhuA A1-159_C545_V548_F501_tev), CD (circular dichroism), ESIMS (electrospray ionization-mass spectrometry), $\mathrm{NaP}_{\mathrm{i}}$ (sodium phosphate buffer).

\section{Supporting Information}

\section{Supporting Information File 1}

Illustration of the catalyst 2 and NMR spectra of synthesized compounds.

[http://www.beilstein-journals.org/bjoc/content/ supplementary/1860-5397-12-124-S1.pdf]

\section{Acknowledgements}

We gratefully acknowledge the financial support by the Deutsche Forschungsgemeinschaft (DFG) through the International Research Training Group "Selectivity in Chemo- and Biocatalysis" (SeleCa), the excellence cluster "Tailor-made Fuels from Biomass" (TMFB), the JSPS Japan-German Graduate Externship Program, and Grants-in-Aid for Scientific Research (JSPS KAKENHI Grant Number JP15H05804 in Precisely Designed Catalysts with Customized Scaffolding) from MEXT.

\section{References}

1. Lu, Y. Angew. Chem., Int. Ed. 2006, 45, 5588-5601. doi:10.1002/anie.200600168

2. Steinreiber, J.; Ward, T. R. Coord. Chem. Rev. 2008, 252, 751-766. doi:10.1016/j.ccr.2007.09.016

3. Reetz, M. T. Chem. Rec. 2012, 12, 391-406. doi:10.1002/tcr.201100043

4. Lewis, J. C. ACS Catal. 2013, 3, 2954-2975. doi:10.1021/cs400806a

5. Matsuo, T.; Hirota, S. Bioorg. Med. Chem. 2014, 22, 5638-5656. doi:10.1016/j.bmc.2014.06.021

6. Hayashi, T.; Sano, Y.; Onoda, A. Isr. J. Chem. 2015, 55, 76-84. doi:10.1002/ijch.201400123

7. Heinisch, T.; Ward, T. R. Eur. J. Inorg. Chem. 2015, 2015, 3406-3418. doi:10.1002/ejic.201500408

8. Lu, Y.; Yeung, N.; Sieracki, N.; Marshall, N. M. Nature 2009, 460, 855-862. doi:10.1038/nature08304

9. Yu, F.; Cangelosi, V. M.; Zastrow, M. L.; Tegoni, M.; Plegaria, J. S.; Tebo, A. G.; Mocny, C. S.; Ruckthong, L.; Qayyum, H.; Pecoraro, V. L. Chem. Rev. 2014, 114, 3495-3578. doi:10.1021/cr400458x

10. Letondor, C.; Pordea, A.; Humbert, N.; Ivanova, A.; Mazurek, S.; Novic, M.; Ward, T. R. J. Am. Chem. Soc. 2006, 128, 8320-8328. doi:10.1021/ja061580o

11.Zimbron, J. M.; Heinisch, T.; Schmid, M.; Hamels, D.; Nogueira, E. S.; Schirmer, T.; Ward, T. R. J. Am. Chem. Soc. 2013, 135, 5384-5388. doi:10.1021/ja309974s

12. Chatterjee, A.; Mallin, H.; Klehr, J.; Vallapurackal, J.; Finke, A. D.; Vera, L.; Marsh, M.; Ward, T. R. Chem. Sci. 2016, 7, 673-677. doi:10.1039/C5SC03116H 
13. Lo, C.; Ringenberg, M. R.; Gnandt, D.; Wilson, Y.; Ward, T. R. Chem. Commun. 2011, 47, 12065-12067. doi:10.1039/c1cc15004a

14. Mayer, C.; Gillingham, D. G.; Ward, T. R.; Hilvert, D. Chem. Commun. 2011, 47, 12068-12070. doi:10.1039/c1cc15005g

15. Matsuo, T.; Imai, C.; Yoshida, T.; Saito, T.; Hayashi, T.; Hirota, S. Chem. Commun. 2012, 48, 1662-1664. doi:10.1039/c2cc16898g

16. Basauri-Molina, M.; Verhoeven, D. G. A.; van Schaik, A. J.; Kleijn, H.; Klein Gebbink, R. J. M. Chem. - Eur. J. 2015, 21, 15676-15685. doi:10.1002/chem.201502381

17. Philippart, F.; Arlt, M.; Gotzen, S.; Tenne, S.-J.; Bocola, M.; Chen, H.-H.; Zhu, L.; Schwaneberg, U.; Okuda, J. Chem. - Eur. J. 2013, 19, 13865-13871. doi:10.1002/chem.201301515

18. Sauer, D. F.; Bocola, M.; Broglia, C.; Arlt, M.; Zhu, L.-L.; Brocker, M.; Schwaneberg, U.; Okuda, J. Chem. - Asian J. 2015, 10, 177-182. doi:10.1002/asia.201403005

19. Sauer, D. F.; Himiyama, T.; Tachikawa, K.; Fukumoto, K.; Onoda, A.; Mizohata, E.; Inoue, T.; Bocola, M.; Schwaneberg, U.; Hayashi, T.; Okuda, J. ACS Catal. 2015, 5, 7519-7522. doi:10.1021/acscatal.5b01792

20. Zhao, J.; Kajetanowicz, A.; Ward, T. R. Org. Biomol. Chem. 2015, 13, 5652-5655. doi:10.1039/C5OB00428D

21.Zhang, C.; Srivastava, P.; Ellis-Guardiola, K.; Lewis, J. C. Tetrahedron 2014, 70, 4245-4249. doi:10.1016/j.tet.2014.03.008

22. Reetz, M. T.; Jiao, N. Angew. Chem., Int. Ed. 2006, 45, 2416-2419. doi:10.1002/anie.200504561

23. Podtetenieff, J.; Taglieber, A.; Bill, E.; Reijerse, E. J.; Reetz, M. T. Angew. Chem., Int. Ed. 2010, 49, 5151-5155. doi:10.1002/anie.201002106

24. Deuss, P. J.; Popa, G.; Slawin, A. M. Z.; Laan, W.; Kamer, P. C. J. ChemCatChem 2013, 5, 1184-1191. doi:10.1002/cctc.201200671

25. Bos, J.; Fusetti, F.; Driessen, A. J. M.; Roelfes, G. Angew. Chem., Int. Ed. 2012, 51, 7472-7475. doi:10.1002/anie.201202070

26. Himiyama, T.; Sauer, D. F.; Onoda, A.; Spaniol, T. P.; Okuda, J.; Hayashi, T. J. Inorg. Biochem. 2016, 158, 55-61. doi:10.1016/j.jinorgbio.2015.12.026

27. Ghattas, W.; Cotchico-Alonso, L.; Maréchal, J.-D.; Urvoas, A.; Rousseau, M.; Mahy, J.-P.; Ricoux, R. ChemBioChem 2016, 17, 433-440. doi:10.1002/cbic.201500445

28. Nicolaou, K. C.; Snyder, S. A.; Montagnon, T.; Vassilikogiannakis, G. Angew. Chem., Int. Ed. 2002, 41, 1668-1698. doi:10.1002/1521-3773(20020517)41:10<1668::AID-ANIE1668>3.0.CO ;2-Z

29. Reymond, S.; Cossy, J. Chem. Rev. 2008, 108, 5359-5406. doi:10.1021/cr078346g

30. Kagan, H. B.; Riant, O. Chem. Rev. 1992, 92, 1007-1019. doi:10.1021/cr00013a013

31. Tenne, S.-J.; Schwaneberg, U. Int. J. Mol. Sci. 2012, 13, 2459-2471. doi:10.3390/ijms13022459

32. Otto, S.; Engberts, J. B. F. N.; Kwak, J. C. T. J. Am. Chem. Soc. 1998, 120, 9517-9525. doi:10.1021/ja9816537

33. Fulmer, G. R.; Miller, A. J. M.; Sherden, N. H.; Gottlieb, H. E.; Nudelman, A.; Stoltz, B. M.; Bercaw, J. E.; Goldberg, K. I. Organometallics 2010, 29, 2176-2179. doi:10.1021/om100106e

34. Occhipinti, G.; Jensen, V. R.; Törnroos, K. W.; Frøystein, N. Å.; Bjørsvik, H.-R. Tetrahedron 2009, 65, 7186-7194. doi:10.1016/j.tet.2009.05.095

35. Perera, A. S.; Subbaiyan, N. K.; Kalita, M.; Wendel, S. O.; Samarakoon, T. N.; D'Souza, F.; Bossmann, S. H. J. Am. Chem. Soc. 2013, 135, 6842-6845. doi:10.1021/ja403090x
36. Constable, E. C.; Ward, M. D. Dalton Trans. 1990, 1405-1409. doi:10.1039/DT9900001405

37. de Figueiredo, R. M.; Oczipka, P.; Fröhlich, R.; Christmann, M. Synthesis 2008, 1316-1318. doi:10.1055/s-2008-1032016

\section{License and Terms}

This is an Open Access article under the terms of the Creative Commons Attribution License (http://creativecommons.org/licenses/by/2.0), which permits unrestricted use, distribution, and reproduction in any medium, provided the original work is properly cited.

The license is subject to the Beilstein Journal of Organic Chemistry terms and conditions:

(http://www.beilstein-journals.org/bjoc)

The definitive version of this article is the electronic one which can be found at: doi:10.3762/bjoc. 12.124 